\title{
Review
}

\section{Cellulose: A review as natural, modified and activated carbon adsorbent}

\author{
Suhas ${ }^{\text {a,* }}$, V.K. Gupta ${ }^{\text {b }}$, P.J.M. Carrott ${ }^{c}$, Randhir Singh ${ }^{a}$, Monika Chaudhary ${ }^{a}$, Sarita Kushwaha ${ }^{a}$ \\ ${ }^{a}$ Department of Chemistry, Gurukula Kangri Vishwavidyalaya, Haridwar 249404, India \\ ${ }^{\mathrm{b}}$ Department of Applied Chemistry, University of Johannesburg, Johannesburg, South Africa

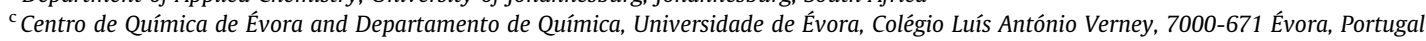

\section{H I G H L I G H T S}

- Cellulose has potential to be used as natural/modified adsorbent.

- Natural cellulose shows lower adsorption capacity as compared to modified cellulose.

- Cellulose can be a promising precursor for production of activated carbon.

- Potential applications of activated carbons from cellulose in adsorption are reviewed.

- Scope for future work on activated carbons from cellulose is discussed.

\section{A R T I C L E I N F O}

\section{Article history:}

Received 22 April 2016

Received in revised form 25 May 2016

Accepted 26 May 2016

Available online 28 May 2016

\section{Keywords:}

Activated carbon

Adsorbent

Adsorption

Cellulose

Lignocellulosic

\begin{abstract}
A B S T R A C T
Cellulose is a biodegradable, renewable, non-meltable polymer which is insoluble in most solvents due to hydrogen bonding and crystallinity. Natural cellulose shows lower adsorption capacity as compared to modified cellulose and its capacity can be enhanced by modification usually by chemicals. This review focuses on the utilization of cellulose as an adsorbent in natural/modified form or as a precursor for activated carbon $(\mathrm{AC})$ for adsorbing substances from water. The literature revealed that cellulose can be a promising precursor for production of activated carbon with appreciable surface area $\left(\sim 1300 \mathrm{~m}^{2} \mathrm{~g}^{-1}\right)$ and total pore volume $\left(\sim 0.6 \mathrm{~cm}^{3} \mathrm{~g}^{-1}\right)$ and the surface area and pore volume varies with the cellulose content. Finally, the purpose of review is to report a few controversies and unresolved questions concerning the preparation/properties of ACs from cellulose and to make aware to readers that there is still considerable scope for future development, characterization and utilization of ACs from cellulose.
\end{abstract}

(c) 2016 Elsevier Ltd. All rights reserved.

\section{Contents}

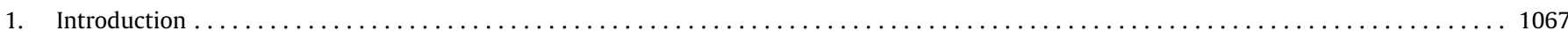

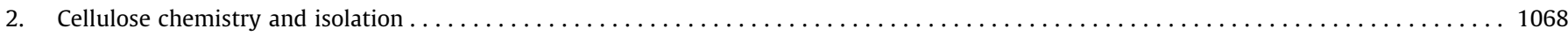

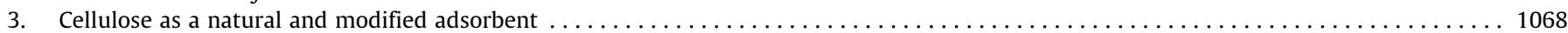

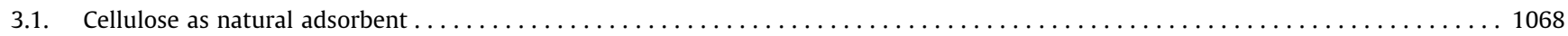

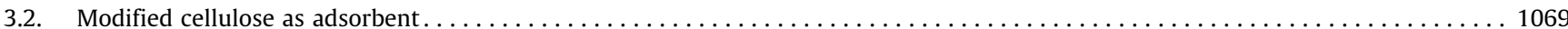

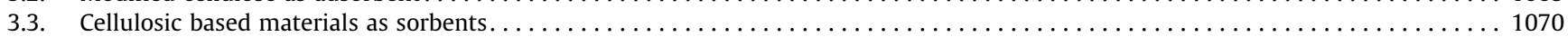

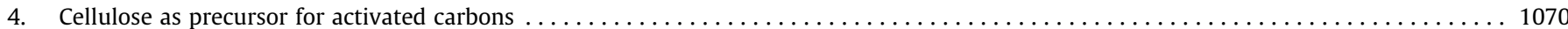

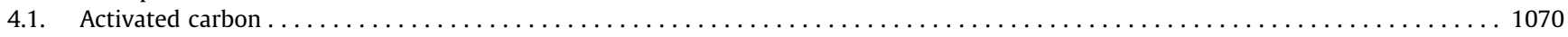

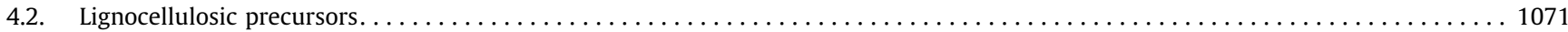

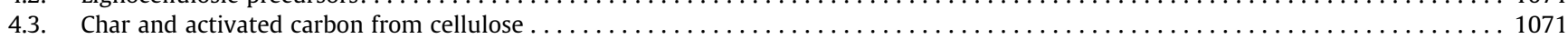

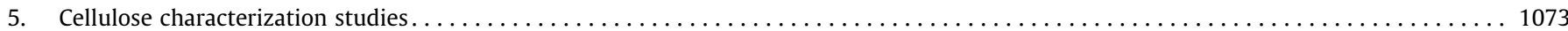

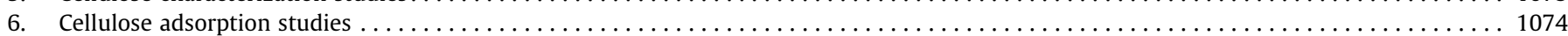

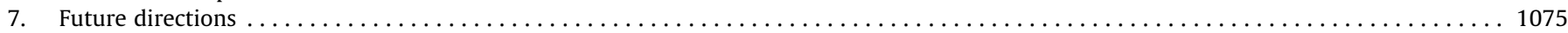

\footnotetext{
* Corresponding author.

E-mail address: suhasnatyan@yahoo.com ( Suhas).
} 
8. Conclusions.

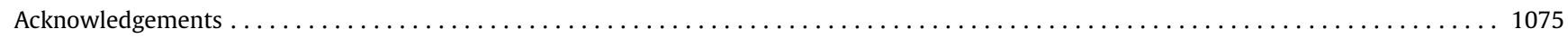

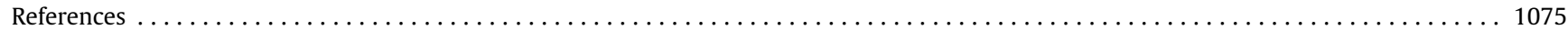

\section{Introduction}

Cellulose is the most copious natural raw material with total production of $10^{11}-10^{12}$ tons/year (Brunner and Roberts, 1980; Huber et al., 2012; Perepelkin, 2004). It is a cheap, biodegradable and renewable polymer which is fibrous, tough and water insoluble and helps in sustaining the structure of the cell walls of plants, oomycetes and algae. The credit for the systematic study of cellulose chemistry goes to a French agricultural chemist Anselme Payen who in 1837-1842 found that all young plants contain a fibrous substance having a uniform chemical substance which was termed by the French Academy as 'cellulose'. On the other hand, the first modified cellulose was discovered by Braconnot in 1839 (Hon, 1994; Huber et al., 2012; Klemm et al., 2005).

Commercial sources of cellulose include mainly wood or cotton. However, cellulose can also be extracted from different parts of plants and other sources, but it is worthwhile mentioning here that the content of cellulose varies from source to source and the values for a few materials have been summarized in Table 1. It can be seen from the table that natural sources such as cotton may contain as high as $\sim 98 \%$ of cellulose, and some types of wood may have as much as $\sim 90 \%$. However, there are other materials, such as the inner seed of mango pits and tomato leaves (Table 1) that have been found to have a cellulose content as low as 14.5 and $10.9 \%$, respectively. Interestingly, the table also shows that different parts of same lignocellulosic material, may contain different amount of cellulose (Table 1).

Cellulose and many cellulose products are harmless to the environment because they safely return to the natural carbon cycle by a simple decay process in the presence of decomposers. Cellulose shows characteristic properties such as hydrophilicity, potential as a sorbent, non-toxicity, facile chemical modification, good mechanical properties, and last but not least, safe disposability after use (Klemm, 1998). Although cellulose has numerous applications and uses, in the present scenario the large volumes of cellulosic waste materials which are originating from agricultural or industrial activities are often regarded as worthless. One possible utilization of this huge amount of a renewable and biodegradable raw material available from different sources can be as a sorbent in various forms such as raw cellulose or modified cellulose or ACs, to eliminate pollutants such as dyes, phenols, metals, pesticides etc. from water. Natural cellulose (Wu et al., 2012) can be utilized as an adsorbent yet, owing to its low adsorption capacity, cellulose is also modified (Wu et al., 2012). The capacities of modified cellulose (He et al., 2014; Karnitz et al., 2009; O'Connell et al., 2008) for the removal of various pollutants are observed to be significant and are comparable, in many cases, to some other naturally existing absorbent materials as well as to commercial ion exchange resins.

Comparatively low adsorption capacities of natural/modified cellulose and the wide applicability of ACs has prompted researchers to explore possibilities of preparing ACs from renewable sources like cellulose and cellulosic materials and to tailor them for specific applications. Besides being used as a precursor for ACs adsorbents another possible application of cellulose is to prepare gaseous or liquid fuels and chars by pyrolysis processes. Recently, such chars have also been studied as possible adsorbents for the removal of pollutants during waste water treatment.

Cellulose is one of the basic constituents of lignocellulosic materials which are widely used as adsorbents, in natural/modified form or as precursors for ACs. It is worthwhile mentioning here that various reviews (Abdolali et al., 2014; Miretzky and Cirelli,

Table 1

Composition in cellulose, lignin, hemicellulose and ash of lignocellulosic materials.

\begin{tabular}{|c|c|c|c|c|c|c|}
\hline Reference & \multicolumn{2}{|l|}{ Raw material } & Cellulose (\%) & Hemicellulose (\%) & Lignin (\%) & Ash (\%) \\
\hline Tiryaki et al. (2014) & \multicolumn{2}{|l|}{ Almond shell } & 21.7 & 27.7 & 36.1 & 6.8 \\
\hline Figueiredo et al. (2010) & \multicolumn{2}{|l|}{ Bagasse } & 40 & 30 & - & - \\
\hline Phan et al. (2006) & \multicolumn{2}{|l|}{ Coconut fibres } & 64 & - & 22 & 0.7 \\
\hline Daud and Ali (2004) & \multicolumn{2}{|l|}{ Coconut shell } & 19.8 & 68.7 & 30.1 & - \\
\hline Lv and Wu (2012) & \multicolumn{2}{|l|}{ Corn stalk } & 42.4 & 29.6 & 21.7 & 5.1 \\
\hline Figueiredo et al. (2010) & \multicolumn{2}{|l|}{ Cornstalk } & 35 & 25 & - & - \\
\hline Perepelkin (2004) & \multicolumn{2}{|c|}{ Cotton as natural fibre } & $97-98$ & - & - & - \\
\hline Abdolali et al. (2014) & \multicolumn{2}{|c|}{ Cotton waste } & $80-95$ & $5-20$ & - & $<1$ \\
\hline Reed and Williams (2004) & \multicolumn{2}{|l|}{ Flax } & 56.5 & - & 2.5 & - \\
\hline Perepelkin (2004) & \multicolumn{2}{|l|}{ Flax } & $80-8$ & - & $3-5$ & - \\
\hline \multirow[t]{2}{*}{ Reed and Williams (2004) } & \multicolumn{2}{|l|}{ Hemp } & 67 & - & 3.3 & - \\
\hline & \multicolumn{2}{|l|}{ Jute } & 64.4 & - & 11.8 & - \\
\hline Gopal and Mathew (1986) & \multicolumn{2}{|l|}{ Jute fibre } & 61 & 24 & 11.5 & 1.6 \\
\hline Phan et al (2006) & \multicolumn{2}{|l|}{ Jute fibre } & $58-63$ & $20-22$ & - & 0.62 \\
\hline Gopal and Mathew (1986) & \multicolumn{2}{|l|}{ Jute stick } & 40.8 & 32.9 & 23.5 & 0.8 \\
\hline Figueiredo et al. (2010) & \multicolumn{2}{|c|}{ Low nonlignified fibre plants } & $70-95$ & $5-25$ & - & - \\
\hline \multirow[t]{2}{*}{ Elizalde-Gonzalez and Hernandez-Montoya (2007) } & \multirow[t]{2}{*}{ Mango pit } & Seed & 14.5 & 52.4 & 3.8 & - \\
\hline & & Outer husk & 39.4 & 15.6 & 5.6 & - \\
\hline Figueiredo et al. (2010) & \multicolumn{2}{|c|}{ Mono cotyledon stem } & $25-40$ & $25-50$ & - & - \\
\hline \multirow[t]{3}{*}{ Ahmad et al. (2011) } & \multirow[t]{3}{*}{ Oil palm biomass } & Bark & 18.85 & - & 21.8 & - \\
\hline & & Shells & 29.7 & & 53.4 & \\
\hline & & Mid-part of trunk & 50.2 & - & 20.2 & - \\
\hline Daud and Ali (2004) & \multicolumn{2}{|l|}{ Palm shell } & 29.7 & - & 53.4 & - \\
\hline Dridi-Dhaouadi et al. (2011) & \multicolumn{2}{|l|}{ Posidonia oceanica } & 38 & 21 & 27 & - \\
\hline Tiryaki et al. (2014) & \multicolumn{2}{|l|}{ Tomato leaves } & 10.9 & 8.1 & 24.8 & 25.7 \\
\hline & \multicolumn{2}{|l|}{ Tomato stems } & 27 & 21 & 16 & 10.6 \\
\hline Perepelkin (2004) & \multicolumn{2}{|l|}{ Wood (coniferous) } & $80-90$ & - & $1-3$ & - \\
\hline
\end{tabular}


2010; Mohamad Nor et al., 2013; Tran et al., 2015) are available on lignocellulosic materials discussing their role as adsorbents and even a few reviews specifically for adsorption of heavy metals by modification of cellulose (O'Connell et al., 2008) are also available. Besides these, the use of the other principal constituent of lignocellulosic materials, namely lignin, as an adsorbent material has been reviewed too (Suhas et al., 2007). Nevertheless, till now no detailed review is available discussing state of art of conversion of cellulose into chars and ACs and the use as natural, modified and ACs adsorbents of these materials.

\section{Cellulose chemistry and isolation}

Cellulose (Demirbas, 2008; Figueiredo et al., 2010; Huber et al., 2012; Klemm, 1998; Kocherbitov et al., 2008) is a linear syndiotactic homopolymer with molecular formula $\left(\mathrm{C}_{6} \mathrm{H}_{10} \mathrm{O}_{5}\right)_{n}$ and made up of D-anhydroglucopyranose units (AGU), commonly called glucose units. The glucose units combine together by $\beta$-(l-4)-glycosidic bonds to form a dimer known as cellobiose which is a fundamental unit of cellulose (Fig. 1) and the cellulose can be considered as an isotactic polymer of cellobiose (Klemm, 1998). The complete hydrolysis of cellulose in the presence of acid gives glucose, which confirms the fact that cellulose is made up of glucose units (Hon, 1994). The $\beta$-D-glucose units combine together by covalent bonds between the equatorial $\mathrm{OH}$ group of $\mathrm{C}-4$ of one glucose unit and the $\mathrm{C}-1$ carbon atom of the next glucose unit to form cellulose and can be characterized by its properties such as biodegradability, hydrophilicity, chirality and broad chemical modifying capacity (Emsley and Stevens, 1994; Figueiredo et al., 2010; Klemm et al., 2005). It is interesting to note that the hydroxyl groups of the cellulose chain at both ends show different behaviour such as the C-1 end of cellulose shows reducing properties, while the C- 4 hydroxy group of the same chain is non-reducing (Klemm, 1998). Cellulose contains a large number of polar oxygen and hydrogen atoms, which are involved in the formation of intermolecular and intramolecular hydrogen bonds between the same and neighbouring cellulose chains and provides stiffness to cellulose chains (Demirbas, 2008; Kocherbitov et al., 2008).

Cellulose (Hon, 1994; Huber et al., 2012) generally has four main polymorphs viz. cellulose I, II, III and IV. Of these, cellulose I is a natural polymorph and is the most crystalline type existing in two forms: $I_{\alpha}$ and $I_{\beta}$, which are similar to each other but the packing pattern in the lattice is different, due to a different extent of hydrogen bonding existing between the chains. Cellulose II has

$$
\frac{\mathrm{HO}}{3{ }_{\mathrm{OH}^{1}}} \mathrm{OH}
$$

Glucose

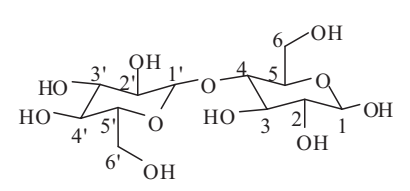

Cellobiose

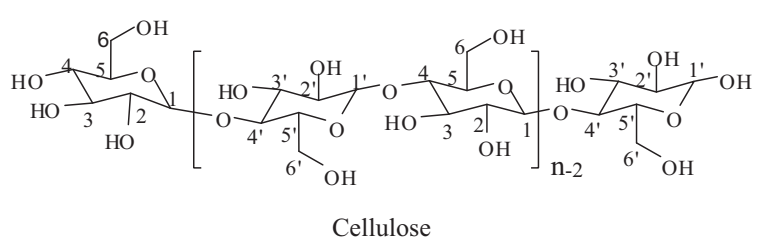

Fig. 1. Structure of glucose, cellobiose and cellulose. an antiparallel arrangement of chains and is obtained by recrystallization of native cellulose. It has been suggested that cellulose II can be formed by two distinct routes, namely mercerization (alkali treatment) or regeneration (solubilization and subsequent recrystallization) of cellulose I. Cellulose III can be prepared from either cellulose I or cellulose II by a treatment with liquid ammonia, resulting in either cellulose $\mathrm{III}_{1}$ or cellulose $\mathrm{III}_{2}$. Cellulose $\mathrm{IV}_{1}$ and cellulose $\mathrm{IV}_{2}$ can be prepared from the corresponding form of cellulose $\mathrm{III}_{1}$ and $\mathrm{III}_{2}$ by heating in glycerol.

Cellulose (Demirbas, 2008; Klemm, 1998) is not meltable and is insoluble in most solvents due to the hydrogen bonding and crystallinity. Furthermore, the crystallinity of cellulose makes it recalcitrant to acid and base-catalyzed hydrolysis too, thereby making the chemical processing of cellulose difficult. Isolation and determination of cellulose can be carried out by various methods which are generally based on its insolubility in organic solvents, water and alkaline solutions, its relative resistance to oxidising agents but susceptibility to hydrolysis by acids. Isolation of cellulose using various other treatment methods involving different steps and environmentally friendly methods have also been carried out and have been described in the literature

\section{Cellulose as a natural and modified adsorbent}

Cellulose has the characteristic physicochemical property of having strong sorption power thereby making it a suitable adsorbent in both forms: natural as well as after modification.

\subsection{Cellulose as natural adsorbent}

Cellulose may be used as a natural adsorbent for various materials including water, organic substances, metal ions, dyes, etc. (Acemioglu and Alma, 2001; Dridi-Dhaouadi et al., 2011; Gupta and Suhas, 2009). The sorption of water vapour is one of the most relevant practical examples for native and regenerated cellulose fibres. A few examples of the sorption of water, nitrogen and other adsorbates are presented in Table 2 and some are discussed in brief here. The study of sorption of water vapour at constant temperature and relative humidity is an important criterion generally used in textile characterization. At low relative humidity a strong chemisorption of water molecules by interaction with the hydroxy groups of the cellulose takes place, whereas at medium relative humidity multilayer sorption takes place and finally at high relative humidity capillary condensation of free water occurs (Klemm, 1998).Water and nitrogen sorption was studied by Kocherbitov et al. (2008) on three types of cellulose viz. Microcrystalline cellulose (MCC) (which was further differentiated on the basis of degree of polymerization as MCC PH-101 and MCC PH301), recrystallized cellulose and amorphous cellulose (which was made by ball milling from MCC). The water sorption was found to be highest for milled MCC (amorphous cellulose) with a BET surface area as observed by water sorption of $264 \mathrm{~m}^{2} \mathrm{~g}^{-1}$ and lowest for the original MCC which had a BET surface area determined by water sorption of $108 \mathrm{~m}^{2} \mathrm{~g}^{-1}$. Interestingly, the enthalpy of water sorption (which was exothermic in nature) was also in the same order. The authors found that the amorphous cellulose takes up more water than MCC because of significant number of sorption sites available on amorphous cellulose compared to MCC, because water molecules can penetrate between the less ordered cellulose chains of amorphous cellulose.

Cellulose as a natural polymeric adsorbent has been studied for the adsorption of metal ions too. Acemioglu and Alma (2001) studied the adsorption of $\mathrm{Cu}(\mathrm{II})$ on cellulose from aqueous solutions. The amount adsorbed was reported to be $7.057 \mathrm{~m}^{2} \mathrm{~g}^{-1}$ and did not differ significantly with temperature. The process was 
Table 2

Surface area and sorption capacity of different types of cellulose.

\begin{tabular}{|c|c|c|c|c|}
\hline Reference & Different types of cellulose & Surface area $(\mathrm{BET})\left(\mathrm{m}^{2} \mathrm{~g}^{-1}\right)$ & Adsorbate & Amount adsorbed \\
\hline $\begin{array}{l}\text { Brunner and Roberts (1980) } \\
\text { Dridi-Dhaouadi et al. (2011) }\end{array}$ & $\begin{array}{l}\text { Cellulose } \\
\text { Cellulose extracted from } P \text {. oceanica }\end{array}$ & $\begin{array}{l}1.4 \text { (using } \mathrm{N}_{2} \text { adsorption) } \\
-\end{array}$ & $\begin{array}{l}- \\
\mathrm{Pb}(\mathrm{II}) \\
\text { Acid yellow } 44\end{array}$ & $\begin{array}{l}- \\
0.264 \mathrm{mmol} \mathrm{g}^{-1} \\
0.028 \mathrm{mmol} \mathrm{g}^{-1}\end{array}$ \\
\hline Lapina and Akhremkova (2006) & Cellulose extracted from Phytoadsorbent SV-I & $\begin{array}{l}54 \text { (using Gravimetric apparatus) } \\
20 \text { (using Gravimetric apparatus) } \\
129 \text { (using Gravimetric apparatus) }\end{array}$ & $\begin{array}{l}\text { Benzene } \\
\text { Methanol } \\
\text { Water }\end{array}$ & $\begin{array}{l}0.22 \mathrm{mmol} \mathrm{g}^{-1} \\
0.18 \mathrm{mmol} \mathrm{g}^{-1} \\
1.72 \mathrm{mmol} \mathrm{g}^{-1}\end{array}$ \\
\hline Liu et al. (2007) & Cotton cellulose & - & Boron & $11.3 \mathrm{mg} \mathrm{g}^{-1}$ \\
\hline Kocherbitov et al. (2008) & $\begin{array}{l}\text { MCC PH-101, cellulose I } \\
\text { MCC PH-301cellulose I } \\
\text { Milled, amorphous cellulose } \\
\text { Milled recrystallized, cellulose II }\end{array}$ & $\begin{array}{l}1.04 \text { (using } \mathrm{N}_{2} \text { adsorption) } \\
124 \text { (using } \mathrm{H}_{2} \mathrm{O} \text { adsorption) } \\
0.55 \text { (using } \mathrm{N}_{2} \text { adsorption) } \\
108 \text { (using } \mathrm{H}_{2} \mathrm{O} \text { adsorption) } \\
0.88 \text { (using } \mathrm{N}_{2} \text { adsorption) } \\
264 \text { (using } \mathrm{H}_{2} \mathrm{O} \text { adsorption) } \\
0.2 \text { (using } \mathrm{N}_{2} \text { adsorption) } \\
223 \text { (using } \mathrm{H}_{2} \mathrm{O} \text { adsorption) }\end{array}$ & - & - \\
\hline Anirudhan and Senan (2011) & Cellulose powder & 18.2 (using $\mathrm{N}_{2}$ adsorption) & & \\
\hline Wu et al. (2012) & Cotton as cellulosic biomass & - & $\mathrm{Pb}(\mathrm{II})$ & $10.78 \mathrm{mg} \mathrm{g}^{-1}$ \\
\hline Virkutyte et al. (2012) & Micro crystalline cellulose & 0.44 (using $\mathrm{N}_{2}$ adsorption) & - & - \\
\hline Monier et al. (2014) & Cotton & 2.432 (using $\mathrm{N}_{2}$ adsorption) & $\begin{array}{l}\mathrm{Au}(\mathrm{III}) \\
\mathrm{Pb}(\mathrm{II}) \\
\mathrm{Ag}^{+}\end{array}$ & $\begin{array}{l}198.31 \mathrm{mg} \mathrm{g}^{-1} \\
87.43 \mathrm{mg} \mathrm{g}^{-1} \\
71.14 \mathrm{mg} \mathrm{g}^{-1}\end{array}$ \\
\hline
\end{tabular}

suggested to be exothermic in nature with a negative standard enthalpy, and the authors also noted the process to be spontaneous in nature with a negative standard free energy. These authors pointed out that the process was first-order and obeyed both the Freundlich and Langmuir models and the $\mathrm{Cu}(\mathrm{II})$ had a monolayer coverage on the adsorbent. $\mathrm{Cu}$ (II) was also studied by Karnitz et al. (2009) who worked on mercerized cellulose and found the removal to be higher than on non-mercerized cellulose at $\mathrm{pH} 3$ and 5.3. They attributed this behaviour to the fact that mercerization transformed the cellulose I to cellulose II which increased the surface area as well as making the cellulose's hydroxy groups more accessible for adsorption.

Cellulose, lignin and melanin were extracted by Lapina and Akhremkova (2006) from Phytoadsorbent SV-1 which is a natural heteropolymer sorbent and a comparative study of the adsorption of benzene, methanol and water vapours on cellulose, lignin and melanin was carried out. The authors suggested that the adsorption depends on the chemical nature as well as on the presence of porosity in the adsorbent. The authors pointed out that micropores with an effective diameter below $0.6 \mathrm{~nm}$ are accessible to water and methanol molecules but inaccessible to benzene molecules. Cellulose was found to have maximum adsorption capacity for water $\left(1.72 \mathrm{mmol} \mathrm{g}^{-1}\right)$ and minimum for methanol $\left(0.18 \mathrm{mmol} \mathrm{g}^{-1}\right)$ even though the cellulose contains a larger number of adsorption sites for benzene as compared to lignin and melanin and specific adsorption of the benzene molecule was suggested to be due to the presence of $\pi$ electrons.

Cotton cellulose was investigated for the removal of boron by Liu et al. (2007). These authors found that the adsorbent showed a good capacity of $11.3 \mathrm{mg} \mathrm{g}^{-1}$ at $\mathrm{pH} 7$ which was mainly due to the $-\mathrm{CHOH}-\mathrm{CHOH}$ containing group. The process was well described by the linear Freundlich isotherm and the authors further suggested that the boron makes a complex with $-\mathrm{CHOH}-$ $\mathrm{CHOH}-$ of the cotton, although the adsorption was suggested to be not only chemical but also physical in nature.

In an interesting review Pyrzynska and Trojanowicz (1999) suggested that unsubstituted cellulose generally has a very low ionexchange capacity, typically in the range of $0.01-0.05 \mathrm{mmol} \mathrm{g}^{-1}$ for trace metals. The presence of carboxyl groups was suggested to be the major part of exchange sites. Moreover, the authors pointed out that sorption of metal ions on cellulose occur more rapidly than with many inorganic collectors like $\mathrm{Al}_{2} \mathrm{O}_{3}$ or $\mathrm{SiO}_{2}$. Anirudhan and Senan (2011) reported that cellulose powder with surface area of $18.2 \mathrm{~m}^{2} \mathrm{~g}^{-1}$ showed a cation exchange capacity of 0.71 mequiv $^{-1}$ at $\mathrm{pH}_{\mathrm{pzc}} 3.5$ and particle size $0.096 \mathrm{~mm}$ and suggested that natural cellulose showed cation exchange capacity which could be enhanced by modification as well as by grafting by chemicals.

The sorption behaviour of $\mathrm{Pb}(\mathrm{II})$ and a dye, acid yellow 44, onto raw Posidonia oceanica cellulose extracted from $P$. oceanica was studied by Dridi-Dhaouadi et al. (2011). The authors identified the site characteristics which play an important role in the adsorption of both dye and metal ions. It was suggested that raw $P$. oceanica had higher sorption value than cellulose for $\mathrm{Pb}$, however, yellow 44 sorption on extracted cellulose was found to be more than on raw P. oceanica. According to the authors this proved that the cellulosic sites play a role in dye sorption. The authors also studied the binary component system of $\mathrm{Pb}(\mathrm{II})$ and dye. It was observed that for raw $P$. oceanica a competition exists between dye and $\mathrm{Pb}(\mathrm{II})$ for the available sites. However, for cellulose it was found to be less which was suggested to be due to the equal availability of cellulosic sites for both pollutants and the only limiting parameter was suggested to be the size of the molecular sorbate. The adsorption of $\mathrm{Pb}(\mathrm{II})$ was also studied by Wu et al. (2012) on cotton as cellulosic biomass and they reported the adsorption capacity of $\mathrm{Pb}$ (II) on cotton to be $10.78 \mathrm{~m}^{2} \mathrm{~g}^{-1}$ at optimum pH 6.0. However, the authors suggested that introduction of thiol groups by modification of the cellulose increased the uptake and this is discussed in subsequent paragraphs. He et al. (2014) studied the adsorption of $\mathrm{Cr}$ (III) and $\mathrm{Fe}(\mathrm{III})$ on cellulose particles and compared with modified cellulose. The saturation adsorption capacities of $\mathrm{Cr}(\mathrm{III})$ and $\mathrm{Fe}(\mathrm{III})$ were found to be 9.78 and $14.29 \mathrm{mg} \mathrm{g}^{-1}$ which were on the lower side and therefore the authors suggested modification of the cellulose which is discussed in the subsequent paragraphs.

\subsection{Modified cellulose as adsorbent}

Modification of cellulose may be carried out to improve the sorption efficiency and physical stability of natural cellulose. Both 
physical as well as chemical properties of natural cellulose can be modified/improved using modification of cellulose and a few findings are discussed here.

Polyethyleneimine (PEI) was introduced to a porous cellulose (Navarro et al., 1996) to modified it and the resulting material (cell-PEI) was found to selectively remove mercury. While studying the effect of $\mathrm{pH}$ the authors observed an unusual behaviour of high metal affinity under acidic conditions. The process was suggested to follow the Langmuir model at low concentrations with appreciable adsorbent capacity of nearly $288 \mathrm{mg} \mathrm{g}^{-1}$. Polyethyleneimine was also used by He et al. (2014) to prepare a porous spherical adsorbent by introducing macromolecular polyethyleneimine on the porous cellulose particles. The modified cellulose was suggested to have better adsorption values than unmodified cellulose for the metals $\mathrm{Cr}$ (III) and $\mathrm{Fe}(\mathrm{III})$ owing to hydrogen bond and chelation interactions. The maximum amount of adsorption for $\mathrm{Cr}$ (III) and $\mathrm{Fe}(\mathrm{III})$ by breakthrough experiments, were found to be 83.98 and $377.19 \mathrm{mg} \mathrm{g}^{-1}$, respectively, which were higher than the unmodified cellulose already discussed in the preceding section.

O'Connell et al. (2006a) in a work on modified cellulose i.e. glycidyl methacrylate-modified cellulose material functionalized using imidazole suggested that this modified cellulose adsorbent has significant potential for the removal of $\mathrm{Ni}(\mathrm{II})$ from aqueous solutions. The authors found that the modified cellulose can remove $48 \mathrm{mg} \mathrm{g}^{-1}$ of nickel from aqueous solution. The process was found to follow a Type I process conforming the Langmuir isotherm. Besides this, the authors derived thermodynamic parameters such as standard free energy change, standard enthalpy change, and standard entropy change. Based on the results the process was suggested to be spontaneous, mildly endothermic and having increased randomness with pseudo-second order kinetics. In a similar study (O'Connell et al., 2006b), interesting results were reported for the sorption of $\mathrm{Pb}$ (II) from aqueous solution on modified cellulose. However, in this study the authors observed that the modified sorbent can remove $72 \mathrm{mg} \mathrm{g}^{-1}$ of $\mathrm{Pb}(\mathrm{II})$ ions with an equilibration time of only $40 \mathrm{~min}$.

Karnitz et al. (2009) prepared modified cellulose using ethylenediaminetetraacetic dianhydride from both nonmercerized and mercerized cellulose and studied the adsorption behaviour of $\mathrm{Cu}^{2+}, \mathrm{Cd}^{2+}$ and $\mathrm{Pb}^{2+}$ ions from aqueous solutions on them and further, compared the adsorption with modified sugarcane bagasse. The modified mercerized adsorbents showed larger maximum adsorption capacities as compared to modified nonmercerized adsorbents for both materials, cellulose as well as sugarcane bagasse. The modified mercerized cellulose had higher Langmuir adsorption capacity than modified non-mercerized cellulose and was found to be 66.7, 112 and $232 \mathrm{mg} \mathrm{g}^{-1}$ for $\mathrm{Cu}^{2+}$, $\mathrm{Cd}^{2+}$ and $\mathrm{Pd}^{2+}$, respectively, at $\mathrm{pH}$ 5.3.

The removal of $\mathrm{Pb}$ (II) from glucose solution on modified (thiolfunctionalized) cellulosic biomass was studied by Wu et al. (2012). The authors observed that unmodified cotton had $\mathrm{Pb}(\mathrm{II})$ adsorption capacity of $10.78 \mathrm{mg} \mathrm{g}^{-1}$ whereas modified cotton could remove $28.67 \mathrm{mg} \mathrm{g}^{-1}$ at $\mathrm{pH} 6$ which was more than twice that of unmodified cotton. The adsorption mechanism resulting in higher removal was suggested to be due to the complexation of lead ions with sulphur atoms from thiol group. The authors proposed that thiolmodified cellulosic biomass can be potentially used for the removal of heavy metal ions in beverage industries. Modified cellulose cotton fibres (Monier et al., 2014) were used for the removal and extraction of precious metals $\mathrm{Au}^{3+}, \mathrm{Pd}^{2+}$ and $\mathrm{Ag}^{+}$. The investigators found that modified cellulose had maximum adsorption capacities as $198.31,87.43$ and $71.14 \mathrm{mg} \mathrm{g}^{-1}$ for $\mathrm{Au}^{3+}, \mathrm{Pd}^{2+}$ and $\mathrm{Ag}^{+}$, respectively and the percent removal was suggested to be higher than unmodified cellulose due to more functional groups and accessibility to active sites. The mechanism through which the modified cellulose bound comparatively more to the unmodified cellulose was suggested to be the coordination step, in which azomethines $(\mathrm{C}=\mathrm{N})$ and thione/thiol $(\mathrm{C}=\mathrm{S} / \mathrm{C}-\mathrm{SH})$ of the inserted phenyl thiosemicarbazide moieties were able to coordinate with the metal ions through chelation mode, which was similar to the observation made by He et al. (2014).

Modified cellulose has been used for the removal of other substances too (Wang and Li, 2013; Zhou et al., 2015). Chemically modified (with quaternary ammonium groups) cellulose from flax shive was used by Wang and Li (2013) for the removal of Reactive Red 228 dye. Interestingly strong adsorption affinity was observed by the material prepared which had a removal capacity of $190 \mathrm{mg} \mathrm{g}^{-1}$ of the dye at $20^{\circ} \mathrm{C}$. This was even higher than the commercial ACs used by the investigators. Zhou et al. (2015) prepared modified cellulose and investigated the adsorption after modification with maleic and phthalic anhydrides, and studied the uptake capacity of the materials toward malachite green from aqueous solution. The authors suggested that the maximum adsorption capacities for the removal of malachite green on maleic and phthalic anhydride modified adsorbents were 370 and $111 \mathrm{mg} \mathrm{g}^{-1}$, respectively, and the process followed the Langmuir model in both cases. The authors suggested that owing to good removal capacity the modified cellulose could be used as an effective adsorption material. Based on the discussions in this section it may be suggested that modified cellulose showed better adsorption results owing to binding with new groups by chelation and complexation, however according to authors this may require more studies to better confirm it.

\subsection{Cellulosic based materials as sorbents}

Annadurai et al. (2002) used cellulose based wastes such as banana peel and orange peel for the removal of various dyes. The amount of adsorption was found to be comparatively lower than ACs owing to the surface area difference, 21-24 $\mathrm{m}^{2} \mathrm{~g}^{-1}$, as compared to $600-1000 \mathrm{~m}^{2} \mathrm{~g}^{-1}$ for ACs. The adsorption capacities for banana peel were found to be higher than orange peel for all dyes and were in the order, methyl orange (21 and $20.5 \mathrm{mg} \mathrm{g}^{-1}$ ) $>$ methylene blue ( 20.8 and $\left.18.6 \mathrm{mg} \mathrm{g}^{-1}\right)>$ Rhodamine $\mathrm{B}(20.6$ and $\left.14.3 \mathrm{mg} \mathrm{g}^{-1}\right)>$ Congo red $\left(18.2\right.$ and $\left.14 \mathrm{mg} \mathrm{g}^{-1}\right)>$ methyl violet (12.2 and $11.5 \mathrm{mg} \mathrm{g}^{-1}$ ) > amido black $10 \mathrm{~B}$ (6.5 and $7.9 \mathrm{mg} \mathrm{g}^{-1}$ ) respectively. Li et al. (2008) also utilized orange peel as a cellulose adsorbent but for the adsorption of metal ions. The material was found to biosorb $\mathrm{Zn}(\mathrm{II}), \mathrm{Co}(\mathrm{II}), \mathrm{Cd}(\mathrm{II})$ and $\mathrm{Ni}(\mathrm{II}), 0.76,0.63,0.49$ and $0.46 \mathrm{~mol} \mathrm{~kg}^{-1}$ respectively. However, these adsorption values were comparatively lower than the modified orange peel cellulose studied by them. Some interesting reviews compiling the work done on the development and utilization of adsorbents from lignocellulosic materials are also available (Hubbe et al., 2012, 2011).

\section{Cellulose as precursor for activated carbons}

\subsection{Activated carbon}

ACs are widely used materials owing to their wonderful adsorption capacities and properties. Adsorption on ACs usually occurs due to the large surface area which ranges from 500 to $2000 \mathrm{~m}^{2} \mathrm{~g}^{-1}$ and high pore volumes. Furthermore, they usually adsorb a wide variety of substances as they are usually not selective because of Van der Waals forces of attraction. Going back in history, carbons have been used for water treatment and medicinal purpose by ancient Indians and Egyptians. However, the modern commercial ACs were developed and patented by Raphael von Ostrejko in 1900 and 1901 (Hassler, 1963). The ACs are generally available in two major forms: granular ACs (GAC) and powdered ACs (PAC), each having its own advantages and disadvantages. 
ACs are usually prepared from materials such as wood, coconut shells, coal, peat and lignite (Mattson and Mark, 1971), however various other materials have also been used by researchers as precursors (Carrott et al., 2010; Suhas et al., 2009; Sun et al., 2016) and two key activation methods i.e. physical and chemical activation have been used.

The two methods have their own advantages. For example, physical activation has an advantage over chemical activation because it avoids the incorporation of additives/impurities coming from the activating agents. Microporous as well as ultramicroporous carbons are usually formed by this method. On the other hand, chemical activation is preferred over physical activation owing to the lower temperature and shorter time needed for activating materials. The carbons formed by this method generally have wider micropores and higher pore volumes making them comparatively more suitable for liquid phase adsorption.

\subsection{Lignocellulosic precursors}

Lignocellulosic materials have been widely used as precursors for production of ACs. A large number of studies has been published and some are discussed below: lignocellulosic materials have been found to be suitable for char production and further for ACs (Ahmed and Theydan, 2014; da Silva Lacerda et al., 2015; Duran-Jimenez et al., 2014; Gergova et al., 1994; Reed and Williams, 2004). Gergova et al. (1994) opined that the microstructure of ACs strongly depends on the original plant texture of the precursor and further on the lignin and cellulose content. While working on lignocellulosic materials (white oak and yellow poplar) for developing ACs using chemical activation. Jagtoyen and Derbyshire (1998) found that the cellulose activation can produce a mixture of pore size carbons, whereas in activation of lignin carbons which are mostly microporous are produced.

It is worthwhile to note that some researchers have reported lignin to be the major contributor of chars and ACs (Cagnon et al., 2009), and some have also reported it to be responsible for more surface area and porosity (Kennedy et al., 2004; Sharma et al., 2004), Contrarily other authors have suggested that microporosity is due to cellulose, while it has also been reported that all components of lignocellulosic materials viz. cellulose, lignin and hemicellulose contribute to the porosity of chars and ACs whatever their weight contribution (Cagnon et al., 2009). Ahmed and Theydan (2014) prepared ACs which were microporous in nature from a lignocellulosic biomass, Albizia lebbeck seed pods. The carbon prepared was microporous having surface area $1824.88 \mathrm{~m}^{2} \mathrm{~g}^{-1}$ and micropore volume $0.645 \mathrm{~cm}^{3} \mathrm{~g}^{-1}$. The carbon developed could remove antibiotics viz. ciprofloxacin and norfloxacin from aqueous solutions with maximum removal capacities of 131.14 and $166.99 \mathrm{mg} \mathrm{g}^{-1}$, respectively. The removal of Rhodamine B from aqueous solutions by utilizing ACs developed from three lignocellulosic waste materials, namely carnauba palm leaves, macauba endocarp and pine nut shell, were studied by da Silva Lacerda et al. (2015). Similarly to Gergova et al. (1994) these authors also suggested that the adsorption capacity depends on the lignocellulosic precursor and on the activation procedure. The authors (da Silva Lacerda et al., 2015) found that ACs prepared by chemical activation in the presence of $\mathrm{CaCl}_{2}$, showed better results for the removal of Rhodamine $\mathrm{B}$ when compared to $\mathrm{H}_{3} \mathrm{PO}_{4}$ ACs as a consequence of enhanced mesopore formation. A fairly similar observation was made by Duran-Jimenez et al. (2014) who suggested that adsorption is favoured for ACs developed from lignocellulosic materials when they have mesoporosity. da Silva Lacerda et al. (2015) in their work comparing the components (cellulose, lignin and hemicellulose) of lignocellulosic materials made an interesting observation that the BET surface area and pore volume increase with increase in cellulose content. Besides this, preliminary studies carried out by the workers regarding the impact of cellulose content showed that increase of native cellulose in the precursor's leads to an enhancement of the adsorption properties.

Even some interesting reviews compiling the work done by various authors on development of ACs from lignocellulosic materials and their applications are available too (Mohamad Nor et al., 2013). The authors are also of the opinion that lignocellulosics are appropriate materials for the preparation of ACs having high surface area and pore volume and which can be comparable to commercial ACs.

\subsection{Char and activated carbon from cellulose}

As cellulose has appreciable carbon content, is readily available, renewable and has a proven ability for sorption (Dridi-Dhaouadi et al., 2011; Kocherbitov et al., 2008; Lapina and Akhremkova, 2006; Wu et al., 2012), it can be a suitable material for the preparation of ACs. A brief summary of the work published and which is discussed in consecutive paragraphs is presented in Tables 3 and 4. Moreover, it can be seen from Table 3 that the carbon content in cellulose varies from $40 \%$ to $44 \%$. However, this content may increase above $80 \%$ for carbonized samples and reach in the range of $95 \%$ for ACs. Table 4 specifically summarizes some of the results related to the conditions for developing ACs from cellulose and the resulting surface area and pore volumes, and discussed in detail in subsequent paragraphs.

Powder cellulose (Brunner and Roberts, 1980) was carbonized in the temperature range $200-950{ }^{\circ} \mathrm{C}$ and the carbon and hydrogen content, weight loss, nitrogen and $\mathrm{CO}_{2}$ isotherms, particle size distribution and mercury penetration were determined. The authors observed that micropore volume and micropore opening size depends highly on the heating rate. Pore volume and surface area of slowly carbonized cellulose were found to be four times larger than those of rapidly heated cellulose. The authors even suggested that the molecular sieve properties can be attained in cellulose char by selecting a proper temperature and heating rate.

Khezami et al. (2005) studied cellulose for the production of ACs and compared it with xylan and lignin. Two methods of activation, simple pyrolysis in nitrogen atmosphere and chemical ( $\mathrm{KOH})$ activation were used. While making a comparison of chars during simple pyrolysis the porosity and the surface area of cellulose was found to be quite high (up to $394 \mathrm{~m}^{2} \mathrm{~g}^{-1}$ ) with micropore volume $0.163 \mathrm{~cm}^{3} \mathrm{~g}^{-1}$ compared to lignin and xylan which exhibited low porosity characterized by a small volume of pores $\left(<0.01 \mathrm{~cm}^{3} \mathrm{~g}^{-1}\right)$ and a small surface area less than $10 \mathrm{~m}^{2} \mathrm{~g}^{-1}$. This behaviour was suggested to be due to the crystalline nature of cellulose as compared to the amorphous nature of xylan and lignin. The authors further carried out the chemical activation of the three materials using $\mathrm{KOH}$, and found that compared to chars a considerable amount of porosity is developed in xylan and lignin with BET surface area varying from $10 \mathrm{~m}^{2} \mathrm{~g}^{-1}$ to $925 \mathrm{~m}^{2} \mathrm{~g}^{-1}$ in the case of xylan and to $513 \mathrm{~m}^{2} \mathrm{~g}^{-1}$ in the case of lignin. However, in the case of cellulose the surface area was found to be $678 \mathrm{~m}^{2} \mathrm{~g}^{-1}$ with total pore volume $0.33 \mathrm{~cm}^{3} \mathrm{~g}^{-1}$ which was somewhere between lignin and xylan. The mesopore volume and pore diameter were observed to be more than ACs developed from lignin and xylan. However, the authors concluded that all the basic components of the wood can yield ACs.

In a similar study, physical and chemical properties of an ACs developed from cellulose, xylan and kraft lignin were studied by Guo and Rockstraw (2006). However, contrary to Khezami, the authors carried out research work using acid $\left(\mathrm{H}_{3} \mathrm{PO}_{4}\right)$ activation. The authors observed that carbons produced from cellulose had highest surface area. Moreover, in the whole temperature range $\left(300-500^{\circ} \mathrm{C}\right)$ studied by these workers the surface areas of the ACs from cellulose were observed to be higher compared to those prepared from kraft lignin. Some interesting observations 
Table 3

CHNSO data of raw cellulose and carbonized and ACs derived from cellulose.

\begin{tabular}{|c|c|c|c|c|c|c|c|}
\hline References & Sample & Conditions & $\mathrm{C} \%$ & $\mathrm{H} \%$ & $\mathrm{~N} \%$ & $0 \%$ & $\mathrm{~S} \%$ \\
\hline Navarro et al. (1996) & Cellulose & - & 40.3 & 6.35 & - & - & - \\
\hline Cagnon et al. (2009) & Cellulose & - & 41.8 & 6.4 & $<0.1$ & 51.2 & $<0.3$ \\
\hline Karnitz et al. (2009) & Cellulose & - & 44.44 & 6.17 & 0.00 & - & - \\
\hline $\begin{array}{l}\text { Sevilla and Fuertes } \\
\text { (2009) }\end{array}$ & Cellulose & - & 44.44 & 6.17 & - & 49.38 & - \\
\hline Lv and Wu (2012) & Cellulose & - & 40.92 & 6.2 & - & 52.88 & 0.001 \\
\hline Gao et al. (2012) & Cellulose & - & 42.93 & 9.06 & 0.0045 & 43.69 & - \\
\hline Diakite et al. (2013) & MCC & - & 43.67 & 6.70 & 0.06 & 49.55 & 0.02 \\
\hline \multirow{2}{*}{ Shen et al. (2013) } & Cellulose powder & - & 41.2 & 6.54 & - & 52.26 & - \\
\hline & Cellulose & - & 42.27 & 6.40 & - & 51.33 & - \\
\hline Reza et al. (2015) & MCC & - & 44.1 & 7.4 & 0.00 & - & 0.1 \\
\hline Babel (2003) & Cellulose char & $\mathrm{P}$ up to $400^{\circ} \mathrm{C}$ at rate $3{ }^{\circ} \mathrm{C} / \mathrm{min}$ & 82.66 & 3.85 & - & 14.07 & - \\
\hline \multirow{2}{*}{$\begin{array}{l}\text { Sevilla and Fuertes } \\
\text { (2009) }\end{array}$} & Cellulose hydrochar & HTC at $250{ }^{\circ} \mathrm{C} / 40 \mathrm{~g} \mathrm{~L}^{-1}$ for $4 \mathrm{~h}$ & 72.52 & 4.36 & - & 23.12 & - \\
\hline & Cellulose hydrochar & HTC at $250^{\circ} \mathrm{C} / 320 \mathrm{gL}^{-1}$ for $2 \mathrm{~h}$ & 70.72 & 4.48 & - & 24.80 & - \\
\hline \multirow[t]{2}{*}{ Gao et al. (2012) } & Cellulose char & $\mathrm{C}$ solid residue at $200^{\circ} \mathrm{C}$ & 44.54 & 6.34 & - & 49.12 & - \\
\hline & Cellulose char & $\mathrm{C}$ solid residue at $400{ }^{\circ} \mathrm{C}$ & 72.93 & 3.84 & - & 23.14 & - \\
\hline Shen et al. (2013) & Cellulose char & $\mathrm{P}$ at $500-1000{ }^{\circ} \mathrm{C}$ & $38.13-3.46$ & $5.34-0.13$ & - & $40.16-0.32$ & - \\
\hline \multirow[t]{3}{*}{ Diakite et al. (2013) } & Cellulose hydrochar & $\mathrm{HTC}$ at $190^{\circ} \mathrm{C}$ for $2-10 \mathrm{~h}$ & $42.52-45.02$ & $7.25-6.79$ & $0.08-0.03$ & $47.44-48.03$ & $0.03-0.12$ \\
\hline & Cellulose hydrochar & HTC at $230^{\circ} \mathrm{C}$ for $10 \mathrm{~h}$ and $\mathrm{pH} 3$ & 69.45 & 3.99 & 0.06 & 26.43 & 0.07 \\
\hline & Cellulose hydrochar & HTC at $270^{\circ} \mathrm{C}$ for $6 \mathrm{~h}$ and $\mathrm{pH} 3$ & 75.27 & 2.65 & 0.08 & 21.92 & 0.09 \\
\hline \multirow[t]{2}{*}{ Reza et al. (2015) } & Cellulose hydrochar & HTC for $20 \mathrm{~min}$ & 63.3 & 4.9 & 0.01 & - & 0.3 \\
\hline & Cellulose hydrochar & HTC for $480 \mathrm{~min}$ & 72.8 & 4.6 & 0.00 & - & 0.2 \\
\hline Babel (2003) & Cellulose AC & A at $850{ }^{\circ} \mathrm{C}$ for $30 \mathrm{~min}$ & 95.53 & 0.76 & - & 3.71 & - \\
\hline $\begin{array}{l}\text { Lorenc-Grabowska and } \\
\text { Rutkowski (2014) }\end{array}$ & Cellulose AC & A at $900{ }^{\circ} \mathrm{C} 100^{\circ} \mathrm{C} \mathrm{s}^{-1}$ & 95.08 & 0.66 & 0.09 & 4.17 & 0.00 \\
\hline
\end{tabular}

A - activated, ACs - activated carbon, C - carbonized, P - pyrolyzed, HTC - hydrothermally carbonized, MCC - microcrystalline cellulose.

Table 4

Physical and chemical activation of cellulose.

\begin{tabular}{|c|c|c|c|c|c|c|c|}
\hline Reference & Cellulose used & Activation & Conditions & $\begin{array}{l}\text { Surface } \\
\text { area } \\
\left(\mathrm{m}^{2} \mathrm{~g}^{-1}\right)\end{array}$ & $\begin{array}{l}\text { Micropore } \\
\text { volume } \\
\left(\mathrm{cm}^{3} \mathrm{~g}^{-1}\right)\end{array}$ & $\begin{array}{l}\text { Mesopore } \\
\text { volume } \\
\left(\mathrm{cm}^{3} \mathrm{~g}^{-1}\right)\end{array}$ & $\begin{array}{l}\text { Total pore } \\
\text { volume } \\
\left(\mathrm{cm}^{3} \mathrm{~g}^{-1}\right)\end{array}$ \\
\hline $\begin{array}{l}\text { Khezami et al. } \\
\text { (2005) }\end{array}$ & $\begin{array}{l}\text { Cellulose } \\
\text { (Whatman CF11) }\end{array}$ & $\begin{array}{l}\text { Physical: } \\
\text { carbonization }-\mathrm{N}_{2}\end{array}$ & $\mathrm{C}\left(\right.$ rate $1-10^{\circ} \mathrm{C} / \mathrm{min}, 700^{\circ} \mathrm{C}$ ) & $392-262$ & $0.152-0.108$ & $0.043-0.008$ & $0.195-0.116$ \\
\hline $\begin{array}{l}\text { Miyajima et al. } \\
\text { (2008) }\end{array}$ & $\begin{array}{l}\text { Commercially } \\
\text { available cellulose } \\
\text { power }\end{array}$ & $\begin{array}{l}\text { Physical: } \\
\text { carbonization }-\mathrm{N}_{2}\end{array}$ & $\mathrm{C}\left(400^{\circ} \mathrm{C}, 3 \mathrm{~h}\right)$ & $\sim 30$ & - & - & - \\
\hline \multirow[t]{3}{*}{$\begin{array}{l}\text { Brunner and } \\
\quad \text { Roberts (1980) }\end{array}$} & $\begin{array}{l}\text { Char } 31 \text { from } \\
\text { cellulose }\end{array}$ & $\begin{array}{l}\text { Physical: } \\
\text { carbonization - Ar }\end{array}$ & Char $\left(460^{\circ} \mathrm{C}, 70^{\circ} \mathrm{C} / \mathrm{min}\right)$ & $5.2\left(\mathrm{~N}_{2}\right)$ & 0.002 & - & - \\
\hline & & Carbonization - Ar & Char $\left(460^{\circ} \mathrm{C}, 70^{\circ} \mathrm{C} / \mathrm{min}\right)$ & $370\left(\mathrm{CO}_{2}\right)$ & 0.145 & - & - \\
\hline & Cellulose (Merck) & Carbonization - $\mathrm{Ar}$ & $\begin{array}{l}\text { Carbonized to } 900{ }^{\circ} \mathrm{C} \text {, at a heating } \\
\text { rate } 0.03-70{ }^{\circ} \mathrm{C} / \mathrm{min}\end{array}$ & $\begin{array}{l}610-470 \\
\left(\mathrm{CO}_{2}\right)\end{array}$ & $0.228-0.18$ & - & - \\
\hline \multirow[t]{3}{*}{ Babel (2003) } & Cellulose fibres & Pyrolyzed & $\mathrm{C}\left(400-850^{\circ} \mathrm{C}\right.$ for $\left.30 \mathrm{~min}\right)$ & $603-726$ & $0.259-0.318$ & $0.037-0.034$ & $\begin{array}{l}0.297- \\
0.3520\end{array}$ \\
\hline & Cellulose fibres & Activation-steam & $\begin{array}{l}\mathrm{C}\left(400-600{ }^{\circ} \mathrm{C} \text { for } 30 \mathrm{~min}\right) \text { and } \mathrm{A} \\
\text { (steam) }\end{array}$ & $\begin{array}{l}1020- \\
1044\end{array}$ & $0.394-0.412$ & $0.163-0.158$ & $\begin{array}{l}0.556- \\
0.5698\end{array}$ \\
\hline & & Activation-steam & $\mathrm{C}\left(850^{\circ} \mathrm{C}\right.$ for $\left.30 \mathrm{~min}\right)$ and $\mathrm{A}($ steam $)$ & 940 & 0.3654 & 0.1439 & 0.5093 \\
\hline $\begin{array}{l}\text { Sun and Hong } \\
\text { (2011) }\end{array}$ & $\alpha$-Cellulose & $\begin{array}{l}\text { Carbonization and } \\
\text { activation }\end{array}$ & $\mathrm{C}\left(400^{\circ} \mathrm{C}\right)$ and $\mathrm{A}\left(700^{\circ} \mathrm{C}\right)$ & 432 & 0.213 & 0.020 & 0.233 \\
\hline $\begin{array}{l}\text { Cagnon et al. } \\
\text { (2009) }\end{array}$ & Cellulose & Carbonization $-\mathrm{N}_{2}$ & $\mathrm{C}\left(800^{\circ} \mathrm{C}\right.$ with $\left.5^{\circ} \mathrm{C} \min ^{-1}\right)$ & - & 0.19 & - & 0.19 \\
\hline \multirow{2}{*}{$\begin{array}{l}\text { Lorenc-Grabowska } \\
\text { and Rutkowski } \\
\text { (2014) }\end{array}$} & Cellulose & Activation-steam & $\begin{array}{l}\text { A (steam activation at } 800{ }^{\circ} \mathrm{C} \text { with } \\
5^{\circ} \mathrm{C} \min ^{-1} \text { for } 2 \mathrm{~h} \text { ) }\end{array}$ & - & 0.32 & - & 0.32 \\
\hline & & $\begin{array}{l}\text { Carbonization and } \\
\text { activation }\end{array}$ & $\begin{array}{l}\mathrm{C}\left(400{ }^{\circ} \mathrm{C} \text { for } 3^{\circ} \mathrm{C} \mathrm{min}^{-1}\right) \text { and } \mathrm{A} \text { (steam } \\
\text { activation up to } 900^{\circ} \mathrm{C} \text { with } \\
\left.100{ }^{\circ} \mathrm{C} \mathrm{sec}^{-1}\right)\end{array}$ & 1317 & 0.530 & - & 0.608 \\
\hline Reza et al. (2015) & MCC & Carbonized & $\mathrm{C}\left(250^{\circ} \mathrm{C}\right.$ for $3 \mathrm{~K} \mathrm{~min}^{-1}$ for $\left.6 \mathrm{hr}\right)$ & 21.17 & & & 0.127 \\
\hline $\begin{array}{l}\text { Khezami et al. } \\
\text { (2005) }\end{array}$ & $\begin{array}{l}\text { Cellulose } \\
\text { (Whatman CF11) }\end{array}$ & $\begin{array}{l}\text { Chemical: } \\
\text { Carbonized and } \\
\text { activated } \mathrm{KOH}\end{array}$ & $\begin{array}{l}\mathrm{C}\left(300^{\circ} \mathrm{C}\right) \text { and } \mathrm{A} \text { (heated } 3^{\circ} \mathrm{C} / \mathrm{min} \text { up } \\
\left.\text { to } 700^{\circ} \mathrm{C}\right)\end{array}$ & 678 & 0.284 & 0.049 & 0.333 \\
\hline
\end{tabular}

C - carbonization, A - activation

regarding porosity were made at different temperatures. For instance, below $350{ }^{\circ} \mathrm{C}$, ACs from xylan had the largest micropore volume, followed by carbons from cellulose and kraft lignin, whereas at temperature higher than $400{ }^{\circ} \mathrm{C}$, the micropore volume of ACs from cellulose and xylan were lower than that produced from lignin. While comparing the mesopore volumes of ACs from different precursors at the same activation temperature, the authors noted that at temperature $<350{ }^{\circ} \mathrm{C}$, xylan had the largest mesoporosity whereas at a temperature $>400{ }^{\circ} \mathrm{C}$, cellulose had the largest mesoporosity with the least suggested for the kraft 
lignin sample. For both temperature ranges this observation was quite similar to that observed by Khezami et al. (2005). The authors also suggested that the more reactive the precursor under acidic conditions, the easier is the development of the porosity, primarily mesopores. Cagnon et al. (2009) compared the porosity and other parameters of char and ACs prepared from cellulose, lignin and hemicelluloses using steam activation and reported that chars obtained from cellulose were predominantly microporous with micropore volume $0.19 \mathrm{~cm}^{3} \mathrm{~g}^{-1}$, which was fairly similar to the micropore volume of coconut shell $\left(0.18 \mathrm{~cm}^{3} \mathrm{~g}^{-1}\right)$. Beside this, the ACs prepared from cellulose was also microporous $\left(0.32 \mathrm{~cm}^{3} \mathrm{~g}^{-1}\right)$ in nature. The authors observed that the percentage yield (19.1\%) during char formation from cellulose was lowest as compared to other precursors, whereas the highest percentage yield (86.9\%) was observed for cellulose during ACs formation. The micropore volume observed for ACs developed from cellulose was nearly twice of that observed for cellulose char and interestingly the pore width $(0.58 \mathrm{~nm})$ was less than that for cellulose char $(0.63 \mathrm{~nm})$. However, from this work the authors suggested that although all components contribute to the porosity of chars and ACs, lignin is the major contributor.

In an interesting study Sun and Hong (2011) prepared ACs from cellulose-based polymers including $\alpha$-cellulose along with others having different types of side chain group to see the impact of functional groups on the pore structure of the ACs developed. The carbon from $\alpha$-cellulose was prepared by carbonization in argon at $400{ }^{\circ} \mathrm{C}$ followed by activation in $\mathrm{CO}_{2}$ at $700{ }^{\circ} \mathrm{C}$ and provided an appreciable surface area $\left(432 \mathrm{~m}^{2} \mathrm{~g}^{-1}\right)$ with pore volume $0.233 \mathrm{~cm}^{3} \mathrm{~g}^{-1}$. The authors provided a reason for selecting the activation temperature of $700{ }^{\circ} \mathrm{C}$ which was that below $600^{\circ} \mathrm{C}$ a slow reaction rate occurs whereas above $800^{\circ} \mathrm{C}$ the polymerization degree is boosted and hence there is local graphitization which makes $\mathrm{CO}_{2}$ less effective to create pores. According to these authors an activation temperature of $700{ }^{\circ} \mathrm{C}$ was optimum since it not only permit for the generation of voids but also reduces the graphitization. Besides this, the authors also suggested that ACs prepared from $\alpha$-cellulose does not show a hysteresis loop on the $\mathrm{N}_{2}$ adsorption isotherm which is a clear indication of the absence of mesopores. Interestingly, other polymers (of cellulose) studied by the authors showed hysteresis loops, indicating the presence of mesopores. Lorenc-Grabowska and Rutkowski (2014) prepared ACs which were predominantly microporous in nature using steam activation from the solid residue of co-pyrolysis of cellulose and cellulose/synthetic polymer blends. The surface area of the ACs developed from cellulose was $1317 \mathrm{~m}^{2} \mathrm{~g}^{-1}$ which was comparatively higher than carbons from cellulose synthetic polymer blends i.e. cellulose/polystyrene $\left(1240 \mathrm{~m}^{2} \mathrm{~g}^{-1}\right)$ and cellulose/polypropylene $\left(1235 \mathrm{~m}^{2} \mathrm{~g}^{-1}\right)$. A similar trend was also found in the case of total pore volume $\left(0.608 \mathrm{~cm}^{3} \mathrm{~g}^{-1}\right)$ and micropore volume $\left(0.53 \mathrm{~cm}^{3} \mathrm{~g}^{-1}\right)$ for cellulose ACs which was also higher as compared to other ACs. However, the pore width of cellulose ACs was found to be $1.29 \mathrm{~nm}$ which was in between that of other ACs.

Laszlo et al. (1999) worked on the preparation of porous carbon from packing paper which was used as a source of cellulose by carbonization at $700{ }^{\circ} \mathrm{C}$ followed by activation at $900{ }^{\circ} \mathrm{C}$ in the presence of steam. The authors observed Type IV isotherms with hysteresis loops showing mesopores in a considerable ratio with surface area $659 \mathrm{~m}^{2} \mathrm{~g}^{-1}$. This surface area was comparatively high than polyacrylonitrile fibres $\left(544 \mathrm{~m}^{2} \mathrm{~g}^{-1}\right)$ while quite lower than polyethyleneterephthalate $\left(1254 \mathrm{~m}^{2} \mathrm{~g}^{-1}\right)$ which was also studied by them. A char was prepared from commercially available cellulose fine powder at 300 and $400{ }^{\circ} \mathrm{C}$ by Miyajima et al. (2008), who studied the effect of heating by measuring $\mathrm{N}_{2}$ adsorption isotherms. The authors found a Type III isotherm at $300{ }^{\circ} \mathrm{C}$ with convex curvature to the relative pressure over their entire range with negligible surface area and regarded as non-porous. However, with increase of temperature up to $400^{\circ} \mathrm{C}$, the isotherm slightly changed to Type II and this pyrolyzed cellulose showed BET surface area $\sim 30 \mathrm{~m}^{2} \mathrm{~g}^{-1}$. Hydrothermal carbonization of cellulose was carried out by Sevilla and Fuertes (2009) who prepared highly functionalized carbonaceous material from cellulose in the temperature range 220$250{ }^{\circ} \mathrm{C}$. The interesting part of the process was the low temperature used in the process to produce chars. The char yield was in the range $30-50 \%$, and similarly to other previous studies (Miyajima et al., 2008), the samples showed low porosity with BET surface area $\sim 30 \mathrm{~m}^{2} \mathrm{~g}^{-1}$. The results usually obtained by researchers clearly show that chars in particular, have low porosity and surface area, and need to be activated to produce a more porous material, ACs. Hydrothermal carbonization of cellulose has also been used by Diakite et al. (2013) to develop the chars (also known as hydrochars). According to the authors a temperature range of $230-270{ }^{\circ} \mathrm{C}$ was crucial for the development of their physicochemical properties. The MCC used for the production of hydrochars could develop material having highest surface area of $28.8 \mathrm{~m}^{2} \mathrm{~g}^{-1}$ at $230{ }^{\circ} \mathrm{C}$ which was similar to one reported by Sevilla and Fuertes, whereas, the carbon yields were higher ranging from 63.77 to $69.45 \%$. The authors reported that when temperature increases from 230 to $270{ }^{\circ} \mathrm{C}$ the specific micropore and mesopore volumes decreased owing to the accelerated degradation of the crystallized structure.

\section{Cellulose characterization studies}

Various techniques are being used for characterization of cellulose and chars/ACs from cellulose. Electron microscopic techniques such as SEM and TEM have been used to examine the microstructure and surface morphologies (Klemm, 1998). Some previous studies using these techniques suggested the uniform elementary fibril of cellulose to be $\sim 3.5 \mathrm{~nm}$ in diameter, however, newer investigations showed it to be $3-20 \mathrm{~nm}$ in range. Interestingly, this has been reported to be even more depending on the cellulose source (Fengel and Wegener, 1989). A similar view is available for structures which were observed to be cylindrical rod-like, tape form, depending on source. Literature also shows that at comparatively higher temperature the cellulose yields a porous surface (Diakite et al., 2013).

Cellulosic material properties are very much dependent on the interactions between and within cellulose chains. In order to study these and the changes due to chemical reactions, as well as to study the functional group effect of prepared ACs from cellulose, Fourier Transform Infrared Spectroscopy (FTIR) studies are usually carried out and is well documented in literature. A compilation of observations made by workers show cellulose to have mainly, hydroxyl groups $\left(3200-3600 \mathrm{~cm}^{-1}\right), \mathrm{C}-\mathrm{H}$ stretching from $-\mathrm{CH}_{2}$ groups (2700-3000 $\left.\mathrm{cm}^{-1}\right), \mathrm{C}-\mathrm{O}$ stretching $\left(1000-1300 \mathrm{~cm}^{-1}\right), \mathrm{C}-$ O-C stretching $\left(\sim 1164 \mathrm{~cm}^{-1}\right)$, glycosidic linkages $\left(\sim 895 \mathrm{~cm}^{-1}\right)$. However, some of these bands were suggested to be weakened or even absent after treatment of raw samples and new bands for instance at $1080,1230,1600 \mathrm{~cm}^{-1}$ were reported on heat treatment of cellulose which was suggested to be due to increase in degree of aromatization (Guo and Rockstraw, 2006).

Even information about the changes due to adsorption on cellulose chars were observed by IR absorption analysis. Bradbury and Shafizadeh (1980) while studying the chemisorption of oxygen on cellulose char observed that with increase of heat treatment temperature, the content of oxygen and hydrogen decreases, and therefore, the IR absorption due to functional groups, decreases too. Furthermore, the authors noted that as the chemisorptions proceeds the intensity of various IR absorption bands increase which was suggested to be due to the formation of stable oxygen containing functional groups.

Information such as esterification reaction, crystallinity of cellulose, effect of acid hydrolysis, presence of intramolecular hydrogen 
bonds and differentiation of polymorphs can be obtained with the help of X-ray diffraction. Actually, the degree of crystallinity as well as the dimensions of the crystallites in cellulose has been subject of extensive investigation for many years; some findings of X-ray diffraction measurements of native celluloses have been accomplished (Klemm et al., 2005). A discussion on it is beyond the scope of this review. Cellulose on the basis of XRD is suggested to be crystalline in nature with an intense peak $2 \theta=22.6^{\circ}$.

For a better understanding of cellulose thermochemical conversion, pyrolysis process is usually carried out. Pyrolysis of cellulose (Miyajima et al., 2008) is important since it produce an effect on the surface properties and pore structure of the final product and generally causes complicated physical and chemical changes. The nature of the thermal decomposition of cellulose (Brunner and Roberts, 1980) is complex due to many interrelated reactions with a large number of reactants, intermediates and reaction products. The pyrolysis as recorded by several authors (Brunner and Roberts, 1980; Miyajima et al., 2008) may proceed in four general steps: (i) release of adsorbed water at $<150{ }^{\circ} \mathrm{C}$ (ii) dehydration of glucopyranose units in range $150-240{ }^{\circ} \mathrm{C}$ (iii) depolymerization and breaking of $\mathrm{C}-\mathrm{O}$ and $\mathrm{C}-\mathrm{C}$ bonds within ring units at 240$400{ }^{\circ} \mathrm{C}$ (iv) aromatization or formation of graphenic layers at $400-700^{\circ} \mathrm{C}$. Several reviews (Collard and Blin, 2014), some discussing cellulose, whereas others broadly discussing lignocellulosics and biomass but reviewing cellulose too are already available in the literature. A nice review on the degradation of cellulose in the low temperature region is already available by Emsley and Stevens (1994), where the authors reviewed the chemical mechanisms of degradation. Also, an interesting overview on pyrolysis (Collard and Blin, 2014) of biomass constituent discussing mechanism of cellulose conversion and its interaction with other constituents is also available.

\section{Cellulose adsorption studies}

Chars and ACs prepared from cellulose (discussed already in the preceding paragraphs), have also been studied for their adsorption behaviour towards adsorbates both in the gas as well as in the liquid phase, and some of them are discussed below.

The removal of phenol from aqueous solution has been studied by Laszlo et al. (1999) who prepared porous carbon utilizing packing material as a source of cellulose. They suggested that the adsorption of organic molecules from aqueous solution by porous carbon depends on the surface functional groups too, especially on oxygen containing groups. The cellulose carbon was found to adsorb $1.06 \mathrm{mmol} \mathrm{g}^{-1}$ of phenol which was found to be higher than polyacrylonitrile, while lower than polyethyleneterephthalate studied by them. The isotherms were found to be of type $L$ of the Giles classification suggesting excess of acidic surface groups on the carbon. ACs from cellulose (Khezami et al., 2005) was used to study methylene blue and phenol to determine the adsorption capacity and, based on regression coefficients, the Langmuir equation was found to give a better fit than the Freundlich equation. Cellulose was found to have $\mathrm{q}_{\max }$ value of $82.68 \mathrm{mg} \mathrm{g}^{-1}$ and $114.23 \mathrm{mg} \mathrm{g}^{-1}$ for methylene blue and phenol, respectively. The adsorption capacity was further compared with xylan, wood and lignin and was found to be in the same order as that of BET surface area, which was xylan $>$ wood $>$ cellulose $>$ lignin. ACs (LorencGrabowska and Rutkowski, 2014) prepared by steam activation of solid residue of pyrolysis of cellulose and polymers were suggested to be very efficient for phenol removal. The adsorption process was found to follow the Langmuir model resulting in theoretical adsorption capacities ranging from 312 to $417 \mathrm{mg} \mathrm{g}^{-1}$. The researchers suggested that cellulose ACs shows maximum adsorption capacity $\left(417 \mathrm{mg} \mathrm{g}^{-1}\right.$ ) as compared to other cellulose polymer blended ACs. The main mechanism suggested for phenol adsorption was micropore filling in pores with size smaller than $1.4 \mathrm{~nm}$. Besides this, the authors also suggested that further enhancement of adsorption is due to attraction forces between negatively charged phenol molecules and positive islands in basal planes. The authors suggested that since cellulose ACs contains higher oxygen content therefore it creates more positive islands in the basal planes and which could explain its higher adsorption capacity towards phenol as compared to other cellulose/polymer blend ACs. Similar to Laszlo, here also the authors suggested the equilibrium isotherms is related to the L type of the Giles classification. However, specifically for ACs of cellulose and cellulose/ polymer blends the L4 type was reported.

Chemisorption of oxygen on char prepared by rapid pyrolysis of cellulose has been studied by Bradbury and Shafizadeh (1980), who observed that chars developed at $550{ }^{\circ} \mathrm{C}$ for $1.5 \mathrm{~min}$ showed maximum chemisorption. The Elovich equation was used to describe the kinetics of the chemisorption process and the activation energy was found to increase linearly from 13 to $25 \mathrm{kcal} / \mathrm{mol}$ with increasing oxygen uptake from 0 to $2.5 \mathrm{mmol}_{2} / \mathrm{g}$. The authors observed that although some additives may increase or decrease gasification rates, they have little effect on oxygen chemisorption. A similar work was carried out by Miyajima et al. (2008) who made some interesting observations and suggested that the pyrolyzed cellulose prepared at $400{ }^{\circ} \mathrm{C}$ showed high selectivity to oxygen adsorption due to chemisorption inspite of their small surface area and non-porous nature. The authors observed that the uptake of oxygen increased by two or three times after modification of cellulose with $\mathrm{NaOH}$ or $\mathrm{KOH}$ before heat treatment.

Huang et al. (2001) prepared cellulose based ACs tows (ACT) from cellulose filaments after pre-treatment with complex flame retarding reagents and studied the adsorption of gases $\left(\mathrm{NH}_{3}\right.$ and $\mathrm{SO}_{2}$ ) and organic solvents (chloroform and acetone) on it and compared it with a granular ACs (GAC). The authors found that ACT has better adsorption capacities than that of GAC owing to the high specific surface area $\left(1631 \mathrm{~m}^{2} \mathrm{~g}^{-1}\right)$ and microporosity $\left(0.782 \mathrm{~cm}^{3}\right.$ $\mathrm{g}^{-1}$ ) as compared to GAC (surface area $836 \mathrm{~m}^{2} \mathrm{~g}^{-1}$; microporosity $0.359 \mathrm{~cm}^{3} \mathrm{~g}^{-1}$ ). The amount of adsorption of gases was found to increase with increase in time by ACT and was found to be $60 \mathrm{ppm}$ in $65 \mathrm{~min}$ and $90 \mathrm{ppm}$ in $85 \mathrm{~min}$ for $\mathrm{NH}_{3}$ and $\mathrm{SO}_{2}$, respectively. The authors observed that initially the adsorption of chloroform and acetone on ACT was 42 and $22 \mathrm{wt} \%$, respectively, and thereafter increased slowly reaching the maximum amount of 56.7 and $40.7 \mathrm{wt} \%$ for chloroform and acetone, respectively, whereas the GAC showed maximum adsorption of chloroform and acetone of 37.5 and $27.9 \mathrm{wt} \%$, respectively. Monge et al. (2002) noted that the carbon prepared from cellulose based corrugated paper and impregnated with a petroleum pitch shows some interesting and significant properties, such as molecular sieve, microporosity, resistance to oxidation and stability of the porosity at high heat temperature. It was suggested that these properties make the carbons interesting materials for high temperature applications, either as catalyst supports or for gas separations. Further, the molecular sieve properties of carbons prepared at $1000^{\circ} \mathrm{C}$ were analysed by the authors using $\mathrm{CH}_{4}$ and $\mathrm{CO}_{2}$ adsorption kinetics and they noted that the adsorption of $\mathrm{CH}_{4}$ was slow and small as compared to $\mathrm{CO}_{2}$ which was fast and appreciable.

Sun and Hong (2011) prepared ACs from cellulose and cellulose based polymers (discussed in the preceding paragraph). The authors further studied the adsorption capacities of the ACs prepared by $\mathrm{H}_{2} \mathrm{~S}$ adsorption. They observed that the adsorption of $\mathrm{H}_{2} \mathrm{~S}$ not only depends on surface area and pore volume but also on the basicity which further decided the order of adsorption. The authors observed that the uptake capacity of $\mathrm{H}_{2} \mathrm{~S}$ by ACs prepared from $\alpha$-cellulose was $7.29 \mathrm{mg} \mathrm{g}^{-1}$, which was found to be more than ACs prepared from methyl cellulose and cellulose 
acetate precursors, while lower than that of hydroxyethyl cellulose ACs. Moreover, the authors also suggested that for carbons having similar pH values (ACs from $\alpha$-cellulose and methyl cellulose), the $\mathrm{H}_{2} \mathrm{~S}$ adsorption capacities depend primarily on the specific surface area. Besides this, among these two carbons, one with microporous structure (AC from $\alpha$-cellulose) was suggested to be more influential in the adsorption process of $\mathrm{H}_{2} \mathrm{~S}$ as compared to the other (AC from methyl cellulose) having mesoporous structure. It is worthwhile mentioning here that only a few studies are available regarding the adsorption of liquids and gaseous molecules on ACs from pure cellulose with a few papers discussing in detail the adsorption mechanism, models and kinetics.

In preceding paragraphs/sections we discussed utilization of cellulose in natural/modified or as a precursor for the activated carbon which have their own benefits and shortcomings. Natural cellulose has adsorption sites which play an important role in the removal of various materials including organic substances, metal ions, dyes etc. thereby making it a suitable natural adsorbent. However, the major drawback of natural cellulose is the amount adsorbed which is usually less. Interestingly, modification of cellulose enhances the adsorption amount in comparison to the unmodified cellulose as already mentioned in Section 3.2 due to the binding with some additional groups. Though modified cellulose has this benefit but it has some shortcoming too like for modification purpose chemicals are used which are generally environment unfriendly and not cost effective. On the other hand benefits of activated carbon from cellulose are high surface area, porosity and non-selective nature which makes it better and widely used material. However, the major shortcomings of activated carbon in comparison to natural cellulose are the higher production cost and difficulties associated with its regeneration owing researchers to search better low cost methods for producing activated carbons.

\section{Future directions}

It is evident now that cellulose has potential to be used as an adsorbent in natural/modified form or as precursor for ACs. The literature revealed that a little but promising work has been carried out on the development and utilization of ACs from cellulose precursors. However, the work is not sufficient and lacks systematic studies on it. The proper discussion on the porosity and surface area development during activation of cellulose either by physical or chemical methods may be the issue for future work. Furthermore, the role of different polymorphs of cellulose in the production of ACs and their effects on the porosity and surface area development still need to be explored. A more fundamental mechanistic approach is needed to understand the role of individual components, especially cellulose and lignin, of lignocellulosic materials in the development of porosity as well as surface area and furthermore on adsorption. Besides these, recently some investigations have been carried out on the hydrothermal carbonization of cellulose but more research can be directed in this area to explore about it.

Although some information on the adsorption behaviour of natural/modified cellulose as well as cellulose based ACs is available in the literature, the adsorption mechanisms for the removal of pollutants from waste water still need to be studied in more detail. In addition, the comparison of the adsorption performance of cellulose based adsorbents for the same adsorptive or solute also need detailed research. To date the adsorption studies have been explored only on a lab scale, and research on full scale systems is yet to be explored deeply.

Research is mainly focussed on the technical performance of cellulose, while the economic aspect is usually neglected. Further research is necessary to assess the economic feasibility and the environmental impact of the adsorbents activated from inactivated cellulose. At the present time environmental concerns necessitate that cellulose has no negative impact of its own and may contribute to the sustainability of the environment. Therefore it can be a choice in its natural form, after modification, or as a precursor for ACs.

\section{Conclusions}

The present review on cellulose leads to the conclusion that it arguably has the potential to be used as an adsorbent in natural/modified or as a precursor for activated carbon. Modification of cellulose enhances the sorption efficiency of natural cellulose. Activated carbons developed from cellulose possess appreciable surface areas and pore volumes which usually results in higher adsorption capacities than natural or modified cellulose. There are still some challenges which need to be addressed or explored and there is scope for future work on cellulose.

\section{Acknowledgements}

One of the authors (Monika Chaudhary INSPIRE Fellow code IF120368) is grateful to the DST (Department of Science and Technology), New Delhi, India for the award of a doctoral grant (No. DST/INSPIRE Fellowship/2012/346).

\section{References}

Abdolali, A., Guo, W.S., Ngo, H.H., Chen, S.S., Nguyen, N.C., Tung, K.L., 2014. Typical lignocellulosic wastes and by-products for biosorption process in water and wastewater treatment: a critical review. Bioresour. Technol. 160, 57-66.

Acemioglu, B., Alma, M.H., 2001. Equilibrium studies on adsorption of Cu(II) from aqueous solution onto cellulose. J. Colloid Interface Sci. 243, 81-84.

Ahmad, T., Rafatullah, M., Ghazali, A., Sulaiman, O., Hashim, R., 2011. Oil palm biomass-based adsorbents for the removal of water pollutants-a review. J. Environ. Sci. Health C 29, 177-222.

Ahmed, M.J., Theydan, S.K., 2014. Fluoroquinolones antibiotics adsorption onto microporous activated carbon from lignocellulosic biomass by microwave pyrolysis. J. Taiwan Inst. Chem. Eng. 45, 219-226.

Anirudhan, T.S., Senan, P., 2011. Adsorption characteristics of cytochrome C onto cationic Langmuir monolayers of sulfonated poly(glycidylmethacrylate)-grafted cellulose: mass transfer analysis, isotherm modeling and thermodynamics. Chem. Eng. J. 168, 678-690.

Annadurai, G., Juang, R.S., Lee, D.J., 2002. Use of cellulose-based wastes for adsorption of dyes from aqueous solutions. J. Hazard. Mater. 92, 263-274.

Babel, K., 2003. Porous structure evolution of cellulose carbon fibres during heating in the initial activation stage. Fuel Process. Technol. 85, 75-89.

Bradbury, A.C.W., Shafizadeh, F., 1980. Chemisorption of oxygen on cellulose char. Carbon 18, 109-116.

Brunner, P.H., Roberts, P.V., 1980. The significance of heating rate on char yield and char properties in the pyrolysis of cellulose. Carbon 18, 217-224.

Cagnon, B., Py, X., Guillot, A., Stoeckli, F., Chambat, G., 2009. Contributions of hemicellulose, cellulose and lignin to the mass and the porous properties of chars and steam activated carbons from various lignocellulosic precursors. Bioresour. Technol. 100, 292-298.

Carrott, P.J.M., Ribeiro Carrott, M.M.L., Suhas, 2010. Comparison of the DubininRadushkevich and quenched solid density functional theory approaches for the characterisation of narrow microporosity in activated carbons obtained by chemical activation with $\mathrm{KOH}$ or $\mathrm{NaOH}$ of kraft and hydrolytic lignins. Carbon $48,4162-4169$.

Collard, F.-X., Blin, J., 2014. A review on pyrolysis of biomass constituents: mechanisms and composition of the products obtained from the conversion of cellulose, hemicelluloses and lignin. Renew. Sustainable Energy Rev. 38, 594608.

da Silva Lacerda, V., López-Sotelo, J.B., Correa-Guimarães, A., Hernández-Navarro, S., Sánchez-Báscones, M., Navas-Gracia, L.M., Martín-Ramos, P., Martín-Gil, J., 2015. Rhodamine B removal with activated carbons obtained from lignocellulosic waste. J. Environ. Manage. 155, 67-76.

Daud, W.M.A.W., Ali, W.S.W., 2004. Comparison on pore development of activated carbon produced from palm shell and coconut shell. Bioresour. Technol. 93, 6369.

Demirbas, A., 2008. Heavy metal adsorption onto agro-based waste materials: a review. J. Hazard. Mater. 157, 220-229.

Diakite, M., Paul, A., Jager, C., Pielert, J., Mumme, J., 2013. Chemical and morphological changes in hydrochars derived from microcrystalline cellulose and investigated by chromatographic, spectroscopic and adsorption techniques. Bioresour. Technol. 150, 98-105. 
Dridi-Dhaouadi, S., Douissa-Lazreg, N.B., M’Henni, M.F., 2011. Removal of lead and yellow 44 acid dye in single and binary component systems by raw Posidonia oceanica and the cellulose extracted from the raw biomass. Environ. Technol. $32,325-340$.

Duran-Jimenez, G., Hernandez-Montoya, V., Montes-Moran, M.A., BonillaPetriciolet, A., Rangel-Vazquez, N.A., 2014. Adsorption of dyes with different molecular properties on activated carbons prepared from lignocellulosic wastes by Taguchi method. Microporous Mesoporous Mater. 199, 99-107.

Elizalde-Gonzalez, M.P., Hernandez-Montoya, V., 2007. Characterization of mango pit as raw material in the preparation of activated carbon for wastewater treatment. Biochem. Eng. J. 36, 230-238.

Emsley, A.M., Stevens, G.C., 1994. Kinetics and mechanisms of the low-temperature degradation of cellulose. Cellulose 1, 26-56.

Fengel, D., Wegener, G., 1989. Wood: Chemistry, Ultrastructure, Reactions. Walter de Gruyter, Berlin, New York.

Figueiredo, J.A., Ismael, M.I., Anjo, C.M.S., Duarte, A.P., 2010. Cellulose and derivatives from wood and fibers as renewable sources of raw-materials. In: Rauter, A.P., Vogel, P., Queneau, Y. (Eds.), Carbohydrates in Sustainable Development I: Renewable Resources for Chemistry and Biotechnology, vol. 294, pp. 117-128.

Gao, Y., Wang, X.H., Yang, H.P., Chen, H.P., 2012. Characterization of products from hydrothermal treatments of cellulose. Energy 42, 457-465.

Gergova, K., Petrov, N., Eser, S., 1994. Adsorption properties and microstructure of activated carbons produced from agricultural by-products by steam pyrolysis. Carbon 32, 693-702.

Gopal, M., Mathew, M.D., 1986. The scope for utilizing jute wastes as raw materials in various industries: a review. Agric. Wastes 15, 149-158.

Guo, Y.P., Rockstraw, D.A., 2006. Physical and chemical properties of carbons synthesized from xylan, cellulose, and Kraft lignin by $\mathrm{H}_{3} \mathrm{PO}_{4}$ activation. Carbon $44,1464-1475$.

Gupta, V.K., Suhas, 2009. Application of low-cost adsorbents for dye removal - a review. J. Environ. Manage. 90, 2313-2342.

Hassler, J.W., 1963. Activated Carbon. Chemical Publishing Company Inc., New York.

He, Z., Song, H., Cui, Y., Zhu, W., Du, K., Yao, S., 2014. Porous spherical cellulose carrier modified with polyethyleneimine and its adsorption for $\mathrm{Cr}(\mathrm{III})$ and $\mathrm{Fe}(\mathrm{III})$ from aqueous solutions. Chin. J. Chem. Eng. 22, 984-990.

Hon, D.N.S., 1994. Cellulose: a random walk along its historical path. Cellulose 1,1-25.

Huang, J.M., Wang, I.J., Wang, C.H., 2001. Preparation and adsorptive properties of cellulose - based activated carbon tows from cellulose filaments. J. Polym. Res. 8, 201-207.

Hubbe, M.A., Hasan, S.H., Ducoste, J.J., 2011. Cellulosic substrates for removal of pollutants from aqueous systems: a review. 1. Metals. BioResources 6, $2161-$ 2287.

Hubbe, M.A., Beck, K.R., O’Neal, W.G., Sharma, Y.C., 2012. Cellulosic substrates for removal of pollutants from aqueous systems: a review. 2. Dyes. BioResources 7 , 2592-2687.

Huber, T., Mussig, J., Curnow, O., Pang, S.S., Bickerton, S., Staiger, M.P., 2012. A critical review of all-cellulose composites. J. Mater. Sci. 47, 1171-1186.

Jagtoyen, M., Derbyshire, F., 1998. Activated carbons from yellow poplar and white oak by $\mathrm{H}_{3} \mathrm{PO}_{4}$ activation. Carbon 36, 1085-1097.

Karnitz, O., Gurgel, L.V.A., de Freitas, R.P., Gil, L.F., 2009. Adsorption of Cu(II), Cd(II), and $\mathrm{Pb}(\mathrm{II})$ from aqueous single metal solutions by mercerized cellulose and mercerized sugarcane bagasse chemically modified with EDTA dianhydride (EDTAD). Carbohydr. Polym. 77, 643-650.

Kennedy, L.J., Vijaya, J.J., Sekaran, G., 2004. Effect of two-stage process on the preparation and characterization of porous carbon composite from rice husk by phosphoric acid activation. Ind. Eng. Chem. Res. 43, 1832-1838.

Khezami, L., Chetouani, A., Taouk, B., Capart, R., 2005. Production and characterisation of activated carbon from wood components in powder: cellulose, lignin, xylan. Powder Technol. 157, 48-56.

Klemm, D., 1998. Comprehensive Cellulose Chemistry. Wiley-VCH, Weinheim, New York.

Klemm, D., Heublein, B., Fink, H.P., Bohn, A., 2005. Cellulose: fascinating biopolymer and sustainable raw material. Angew. Chem. Int. Ed. Engl. 44, 3358-3393.

Kocherbitov, V., Ulvenlund, S., Kober, M., Jarring, K., Arnebran, T., 2008. Hydration of microcrystalline cellulose and milled cellulose studied by sorption calorimetry. J. Phys. Chem. B 112, 3728-3734.

Lapina, V.A., Akhremkova, G.S., 2006. Correlations between the adsorption and structural properties of SV-1 phytoadsorbent and its main components. Russ. J. Phys. Chem. A 80, 1164-1166.

Laszlo, K., Bota, A., Nagy, L.G., Cabasso, I., 1999. Porous carbon from polymer waste materials. Colloids Surf. A 151, 311-320.

Li, X., Tang, Y., Cao, X., Lu, D., Luo, F., Shao, W., 2008. Preparation and evaluation of orange peel cellulose adsorbents for effective removal of cadmium, zinc, cobalt and nickel. Colloids Surf. A 317, 512-521.

Liu, R., Ma, W., Jia, C.Y., Wang, L., Li, H.Y., 2007. Effect of pH on biosorption of boron onto cotton cellulose. Desalination 207, 257-267.

Lorenc-Grabowska, E., Rutkowski, P., 2014. High basicity adsorbents from solid residue of cellulose and synthetic polymer co-pyrolysis for phenol removal: kinetics and mechanism. Appl. Surf. Sci. 316, 435-442.
Lv, G.J., Wu, S.B., 2012. Analytical pyrolysis studies of corn stalk and its three main components by TG-MS and Py-GC/MS. J. Anal. Appl. Pyrolysis 97, 11-18.

Mattson, J.S., Mark, H.B.J., 1971. Activated Carbon Surface Chemistry and Adsorption from Solution. Marcel Dekker Inc., New York.

Miretzky, P., Cirelli, A.F., 2010. Cr(VI) and Cr(III) removal from aqueous solution by raw and modified lignocellulosic materials: a review. J. Hazard. Mater. 180, 1 19.

Miyajima, N., Uchida, S., Suzuki, T., Sakane, H., 2008. Oxygen adsorption properties of pyrolyzed cellulose. Mater. Sci. Eng. B Adv. 148, 249-252.

Mohamad Nor, N., Lau, L.C., Lee, K.T., Mohamed, A.R., 2013. Synthesis of activated carbon from lignocellulosic biomass and its applications in air pollution control - a review. J. Environ. Chem. Eng. 1, 658-666.

Monge, J.A., Blanco, C., Solano, A.L., Brydson, R., Rand, B., 2002. Development of new carbon honeycomb structures from cellulose and pitch. Carbon 40, 541-550.

Monier, M., Akl, M.A., Ali, W.M., 2014. Modification and characterization of cellulose cotton fibers for fast extraction of some precious metal ions. Int. J. Biol. Macromol. 66, 125-134.

Navarro, R.R., Sumi, K., Fujii, N., Matsumura, M., 1996. Mercury removal from wastewater using porous cellulose carrier modified with polyethyleneimine. Water Res. 30, 2488-2494.

O'Connell, D.W., Birkinshaw, C., O’Dwyer, T.F., 2006a. A modified cellulose adsorbent for the removal of nickel(II) from aqueous solutions. J. Chem. Technol. Biotechnol. 81, 1820-1828.

O'Connell, D.W., Birkinshaw, C., O'Dwyer, T.F., 2006b. Removal of lead (II) ions from aqueous solutions using a modified cellulose adsorbent. Adsorpt. Sci. Technol. 24, 337-348.

O'Connell, D.W., Birkinshaw, C., O'Dwyer, T.F., 2008. Heavy metal adsorbents prepared from the modification of cellulose: a review. Bioresour. Technol. 99 6709-6724.

Perepelkin, K.E., 2004. Renewable plant resources and processed products in chemical fibre production. Fibre Chem. 36, 161-176.

Phan, N.H., Rio, S., Faur, C., Le Coq, L., Le Cloirec, P., Nguyen, T.H., 2006. Production of fibrous activated carbons from natural cellulose (jute, coconut) fibers for water treatment applications. Carbon 44, 2569-2577.

Pyrzynska, K., Trojanowicz, M., 1999. Functionalized cellulose sorbents for preconcentration of trace metals in environmental analysis. Crit. Rev. Anal. Chem. 29, 313-321.

Reed, A.R., Williams, P.T., 2004. Thermal processing of biomass natural fibre wastes by pyrolysis. Int. J. Energy Res. 28, 131-145.

Reza, M.T., Rottler, E., Tolle, R., Werner, M., Ramm, P., Mumme, J., 2015. Production, characterization, and biogas application of magnetic hydrochar from cellulose. Bioresour. Technol. 186, 34-43.

Sevilla, M., Fuertes, A.B., 2009. The production of carbon materials by hydrothermal carbonization of cellulose. Carbon 47, 2281-2289.

Sharma, R.K., Wooten, J.B., Baliga, V.L., Lin, X.H., Chan, W.G., Hajaligol, M.R., 2004. Characterization of chars from pyrolysis of lignin. Fuel 83, 1469-1482.

Shen, D., Ye, J., Xiao, R., Zhang, H., 2013. TG-MS analysis for thermal decomposition of cellulose under different atmospheres. Carbohydr. Polym. 98, 514-521.

Suhas, Carrott, P.J.M., Carrott, M., 2007. Lignin - from natural adsorbent to activated carbon: a review. Bioresour. Technol. 98, 2301-2312.

Suhas, Carrott, P.J.M., Carrott, M.M.L.R., 2009. Using alkali metals to control reactivity and porosity during physical activation of demineralised kraft lignin. Carbon 47, 1012-1017.

Sun, M., Hong, L. 2011. Impacts of the pendant functional groups of cellulose precursor on the generation of pore structures of activated carbons. Carbon 49 2173-2180.

Sun, Y., Li, H., Li, G., Gao, B., Yue, Q., Li, X., 2016. Characterization and ciprofloxacin adsorption properties of activated carbons prepared from biomass wastes by $\mathrm{H}_{3} \mathrm{PO}_{4}$ activation. Bioresour. Technol. http://dx.doi.org/10.1016/j. biortech.2016.03.047, in press.

Tiryaki, B., Yagmur, E., Banford, A., Aktas, Z., 2014. Comparison of activated carbon produced from natural biomass and equivalent chemical compositions. J. Anal. Appl. Pyrolysis 105, 276-283.

Tran, V.S., Ngo, H.H., Guo, W., Zhang, J., Liang, S., Ton-That, C., Zhang, X., 2015 Typical low cost biosorbents for adsorptive removal of specific organic pollutants from water. Bioresour. Technol. 182, 353-363.

Virkutyte, J., Jegatheesan, V., Varma, R.S., 2012. Visible light activated $\mathrm{TiO}_{2} /$ microcrystalline cellulose nanocatalyst to destroy organic contaminants in water. Bioresour. Technol. 113, 288-293.

Wang, L., Li, J., 2013. Adsorption of C.I. reactive red 228 dye from aqueous solution by modified cellulose from flax shive: Kinetics, equilibrium, and thermodynamics. Ind. Crops Prod. 42, 153-158.

Wu, Z.M., Cheng, Z.H., Ma, W., 2012. Adsorption of $\mathrm{Pb}(\mathrm{II})$ from glucose solution on thiol-functionalized cellulosic biomass. Bioresour. Technol. 104, 807-809.

Zhou, Y., Min, Y., Qiao, H., Huang, Q., Wang, E., Ma, T., 2015. Improved removal of malachite green from aqueous solution using chemically modified cellulose by anhydride. Int. J. Biol. Macromol. 74, 271-277. 